\title{
Animal abundance and food availability: some comments
}

\author{
J.J. Beukema* and G.C. Cadée \\ Netherlands Institute for Sea Research, PO Box 59, 1790 AB Den Burg, Texel, \\ The Netherlands. *Corresponding author, e-mail: janb@nioz.nl
}

\begin{abstract}
We challenge a conclusion reached by Barnes \& de Villiers in a paper that was recently published in this fournal, viz that certain benthic invertebrates occur in lower abundances in lagoons than in intertidal soft-bottom areas and that this difference is due to lower food supply at lagoon bottoms. Our experience in the Wadden Sea shows that food does not limit the abundance of primary consumers in areas where environmental conditions are harsh. Such conditions prevail in most of the upper half of the intertidal which is characterized by low abundance of zoobenthos despite a high food supply.
\end{abstract}

In a recent paper in this periodical, Barnes \& de Villiers (2000) show that standing stocks of deposit-feeding benthic invertebrates (in particular hydrobiids) are significantly lower in some British lagoons (more or less permanently submersed shallow coastal salt-water bodies) than in some nearby intertidal soft-sediment areas (from which type of habitat the lagoons originated). Barnes \& de Villiers explain this difference in primary-consumer biomass by consistent differences in food supply. They present evidence that the lower deposit-feeder biomass in lagoons is a consequence of the frequently lower amounts of benthic chlorophyll- $a$ and other potential food materials at lagoon bottoms than at shallow intertidal sites. They argue that the high light intensities during the longer daily periods at such high intertidal sites provide better growing conditions for microphytobenthos than at almost permanently submerged lagoon bottoms.

In our opinion, the evidence Barnes \& de Villiers present in favour of their hypothesis is insufficient. The underlying negative correlation between submergence times and densities of benthic chlorophyll looks convincing only because they left out the data set of one of the six sites they studied. This one lagoon was characterized by a dense phytoplankton bloom in the water column from which the measured high amount of benthic chlorophyll was assumed to have sedimented out (apparently, no microscopic observations were made to identify the algae). Inclusion of this high amount (observed at a site with a long submergence time) would have spoiled the observed negative correlation completely. A valid reason to omit the data from this particular lagoon would have been that deposit-feeders do not feed on settled algae. However, Cadée (1996) reports that Hydrobia ulvae do graze on settled algae. The reason Barnes \& de Villiers actually give for exclusion of these data, viz that this lagoon supported only few hydrobiids, is close to a circular reasoning. Thus, it remains questionable whether the proposed differences in food supply between lagoons and intertidal sites are a general phenomenon that can explain a generally lower biomass of benthic deposit feeders in lagoons. Only a comparison of many more sites than the present five or six could provide an answer. Certainly, a much broader range of intertidal elevations should be included to show the shape of the relationship of deposit-feeder abundance with submergence time and food supply. For reasons mentioned at the end of these comments, we doubt whether this would yield the suggested monotonous one.

Barnes \& de Villiers seek further answers to the question of whether or not the abundance of deposit feeders is food-limited by correlating data from time series of densities of benthic chlorophyll with biomass of its consumers within the various sites. These correlations turned out to be generally weak. What type of correlation could such an effort yield? High consumer abundance could ultimately result in low food densities by intensive grazing and this process would yield a negative correlation. On the other hand, high food densities could result in high consumer abundance by rapid increase of the consumer population, yielding a positive correlation. Thus a simple correlative approach cannot yield unambiguous answers. Only a prolonged and detailed study of the system, including estimates of rate of increase and individual growth at a range of levels of food supply, could provide the answer sought for. In the case of the migratory hydrobiids such a study might be far from simple.

The available evidence on food limitation in marine softbottom deposit-feeders points to a complex answer: on Wadden Sea tidal flats, food limitation does exist, but it is not universal (Beukema \& Cadée, 1997). Where environmental conditions are otherwise favourable on tidal flats, deposit-feeder biomass can be limited by food supply, as evidenced by a recent proportional increase of such biomass values with increasing amounts of available food in most of the western part of the Wadden Sea (as a consequence of mild eutrophication). This parallel change of food supply and consumer biomass implies that biomass was at the carrying capacity of the habitat in the pre-enrichment period. However, in parts of the Wadden Sea that are characterized by very harsh environmental conditions, total consumer biomass was invariably low and only a few specialized species can thrive. Their food demand was always far below the food supply available and their biomass did not respond to the enhanced food supply. Thus, at harsh conditions it is not food supply that keeps consumer biomass at low levels, but other limiting factors, such as exposure to strong winds and currents or too short immersion times.

On Wadden Sea tidal flats, both rate of primary production and density of benthic chlorophyll- $a$ increase with intertidal elevation, probably as a response to the amount of light reaching the bottom (Cadée \& Hegeman, 1977). Thus, maximal supply of benthic primary food can often be found in areas with the shortest daily submergence times. However, it should be kept in mind that a very short submergence time is also a stress factor for aquatic consumers. Indeed, biomass values of primary consumers do not show such monotonous relationships with elevation. All the species or functional groups of species that we have studied in the Wadden Sea show a bell-shaped relationship. The position 
of the maximal biomass values along the elevation gradient differ between species and groups. Arranged in order of increasing elevation: total zoobenthos (more than half of them being suspension feeders in the Wadden Sea) at a level well below mean-tide level (MTL), total deposit feeders slightly below MTL, and the very numerous and typical surface deposit feeders (such as Corophium volutator and Hydrobia ulvae) close to or slightly above MTL, but far below the mean level of neap high tides where their food organisms show maximal densities (Beukema, 1976; Beukema \& Flach, 1995; J.J.B., unpublished observations). Apparently, at high intertidal levels the abundance of all aquatic species is not limited by food but by short immersion times and within the intertidal realm these species are not replaced by terrestrial ones.

This is publication no. 3502 of the Netherlands Institute for Sea Research (NIOZ).

\section{REFERENCES}

Barnes, R.S.K. \& de Villiers, G.J., 2000. Animal abundance and food availability in coastal lagoons and intertidal marine sediments. Fournal of the Marine Biological Association of the United Kingdom, 80, 193-202.

Beukema, J.J., 1976. Biomass and species richness of the macrobenthic animals living on the tidal flats of the Dutch Wadden Sea. Netherlands Fournal of Sea Research, 10, 236-261.

Beukema, J.J. \& Cadée, G.C., 1997. Local differences in macrozoobenthic response to enhanced food supply caused by mild eutrophication in a Wadden Sea area: food is only locally a limiting factor. Limnology and Oceanography, 42, 1424-1435.

Beukema, J.J. \& Flach, E.C., 1995. Factors controlling the upper and lower limits of the intertidal distribution of two Corophium species in the Wadden Sea. Marine Ecology Progress Series, 125, 117-126.

Cadée, G.C., 1996. Accumulation and sedimentation of Phaeocystis globosa in the Dutch Wadden Sea. Journal of Sea Research, 36, 321-327.

Cadée, G.C. \& Hegeman, J., 1977. Distribution of primary production of the benthic microflora and accumulation of organic matter on a tidal flat area, Balgzand, Dutch Wadden Sea. Netherlands Fournal of Sea Research, 11, 24-41.

\title{
Animal abundance and food availability: reply to Beukema \& Cadée
}

\author{
R.S.K. Barnes \\ University of Cambridge, Department of Zoology, Population and Community Ecology Group, \\ Downing Street, Cambridge, CB2 3EJ. E-mail: rsb1001@cam.ac.uk
}

We agree completely with many of the comments made by Beukema \& Cadée. Clearly 'only a comparison of . . . more sites' and 'a prolongated and detailed study of the system ... could provide the answers sought'. Equally clearly 'in the case of the migratory hydrobiids such a study might be far from simple' [although we would dispute that hydrobiids are 'migratory']. Our contribution most certainly did not purport to be the last word on the subject, and nowhere do we claim to have obtained definitive answers.

Indeed we investigated only bare areas of sediment and further studies would have to include the effects of sea grass beds before any claims could be made concerning lagoons in general. Further, we agree wholeheartedly that relationships between numbers of consumer and consumed can take a variety of forms, including those specified by Beukema \& Cadée. Our point was solely that we found no evidence for any of these at any given site.

The only issue on which our two interpretations appear to be at odds concerns inclusion or otherwise of the Broadwater lagoon in the data set. As our Table 1 shows, and as Beukema \& Cadée highlight, there is no relationship between total chlorophyll on/in the substratum and depth of water or extent of coverage by water across all the sites sampled. We, however, were seeking information on the abundance of benthic consumers of chlorophyll and that of in situ microbenthic organisms in relation to depth, etc. Calculation indicated that Broadwater is irrelevant in this context as insufficient light would penetrate to the lagoon bed to permit net in situ photosynthesis. It is clear to us that the chlorophyll on that lagoon's bed derived from fall out from the dense 'pea-soup' phytoplankton bloom present in the water column, and hence Broadwater was excluded from the data set. It is indeed the case, as Beukema \& Cadée point out, that the mudsnail Hydrobia ulvae may graze sedimented chlorophyll, and it could have been a most interesting situation had that species been present at the site.

However, as shown by our Appendix 1, it was not, and to our knowledge no one has shown that any lagoonal species, including those present in Broadwater, can feed on this material, which in lagoons is likely to be suspended at the sediment/water interface. The bed of the lagoon was in any event effectively devoid of potential chlorophyll feeders $\left(1 \mathrm{~g} \mathrm{~m}^{-2}\right.$ as opposed to $10-35 \mathrm{~g} \mathrm{~m}^{-2}$ at the shallow water sites). Beukema \& Cadée suggest that "a valid reason to omit the data from this particular lagoon would have been that deposit feeders do not feed on the settled algae". With the insertion of 'those' before and 'present at the site' after their 'deposit feeders', we agree. 


\title{
Occurrence of the non-native ascidian Perophora japonica in the Fleet, southern England
}

\author{
B. Baldock* and J.D.D. Bishop ${ }^{\dagger}$ \\ *24 Martel Close, Broadmayne, Dorchester, DT2 8PL. \\ ${ }^{\dagger}$ Marine Biological Association of the United Kingdom, The Laboratory, Citadel Hill, Plymouth, PL1 2PB.
}

\begin{abstract}
The far-eastern ascidian Perophora japonica was first recorded in the British Isles in 1999 from a marina in Plymouth Sound, Devon (Nishikawa et al., 2000), having previously been reported from the coast of north-west France (Monniot \& Monniot, 1985). Here we report its occurrence at a second locality in southern England, the Fleet, a bar-built saline lagoon of conservation importance approximately $130 \mathrm{~km}$ from Plymouth.
\end{abstract}

On 27 July 2000, underwater photographs of what appeared to be Perophora japonica Oka, 1927 were taken by B.B. at Pirates Cove in the Fleet, Dorset, UK, at National Grid Reference (NGR) SY 65731 76866, but no specimens were collected. In 2001, a dense mass again believed to be $P$. japonica was noted on 8 June near the south-eastern end of the Fleet at NGR SY 66205 76142 , and at the same locality on 21 July the characteristic bright yellow terminal buds were evident. Perophora japonica was found at depths of $\sim 2.2-3.8 \mathrm{~m}$ and occupied up to $10 \%$ of the area of available substrate. Samples were collected and the identification confirmed by their subsequent microscopical examination (see Nishikawa et al., 2000, for discussion of distinguishing characters). On a repeat dive at the same location on 24 August $P$. japonica appeared less abundant than before and the yellow buds were less evident. A dive on 25 August revealed the species in low numbers in similar habitat extending north-west to NGR SY 6569976605.

Perophora japonica was thus recorded over a stretch of at least $650 \mathrm{~m}$ of the outer Fleet between The Narrows and Small Mouth, in a habitat equating to the Intermediate Link-Channel Zone of Dyrynda (Dyrynda \& Farnham, 1985). This area had a bottom of mixed muddy sand with pebbles and shell providing attachment for a range of algae and sessile fauna (amongst which a range of ascidians was visually dominant). Along with the adjacent Chesil Beach shingle barrier, the Fleet is a candidate for Special Area of Conservation status (cSAC) under the Habitats Directive, and the arrival of a potentially prominent, space-occupying, non-native species gives cause for concern and suggests the need for continued monitoring. Arrival with shipping visiting Portland Harbour, into which the Fleet opens at Small Mouth, seems a likely route of colonization by P. japonica. Given the likely presence of the species in the Fleet in 2000, slightly less than a year after its discovery in Plymouth Sound, there seems little reason to conclude that $P$. japonica spread to the Fleet from Plymouth.

\section{REFERENCES}

Dyrynda, P.E.J. \& Farnham, W.F., 1985. Benthic communities of a rapids system within the Fleet Lagoon, Dorset. Progress in Underwater Science, 10, 65-82.

Monniot, C. \& Monniot, F., 1985. Apparition de l'ascidie Perophora japonica sur les côtes et dans les ports de la Manche. Comptes-Rendus de la Société de Biogéographie, 61, 111-116.

Nishikawa, T., Bishop, J.D.D. \& Sommerfeldt, A.D., 2000. Occurrence of the alien ascidian Perophora japonica at Plymouth. Fournal of the Marine Biological Association of the United Kingdom, 80, 955-956.

\section{Concerning grey seals killing eider ducks in the Clyde Sea area}

\author{
P.G. Moore \\ University Marine Biological Station Millport (UMBSM), Isle of Cumbrae, Scotland, KA28 0EG. \\ E-mail: pmoore@millport.gla.ac.uk
}

\begin{abstract}
Numerous incidents of grey seals killing eider ducks are reported from Millport Bay, Clyde Sea area (Scotland), during the period March-April 2001, that may relate to reductions in availability of fish in coastal waters and/or to delinquent playfulness in juveniles.
\end{abstract}

Although as fully grown birds at sea, eider ducks, Somateria mollissima, are reported to have few known predators (Ross \&
Furness, 2000), one has previously been documented (Morgan, 1986) as having been attacked by a grey seal (Halichoerus grypus). 
The single incident (17 August 1985) reported by Morgan (loc. cit.), from Pagham Harbour (West Sussex), involved a moulting eider that could not fly.

Compared with fish, eider ducks are an expanding resource locally and are particularly plentiful around Great Cumbrae (mean count 586, for 1996-1999; Waltho, 2001). The numbers of eiders in the Clyde Sea area have increased dramatically over the preceding half century; the population having expanded by some $8.5 \%$ per annum, on average, over that period to a current total of some 20,000 birds (Waltho, 2001). Eider fledglings consistently fall prey in substantial numbers to greater black-backed gulls (Larus marinus) locally (P.G.M., personal observation). A large colony of grey seals now haul out on the inner and outer Eileanns in Millport Bay (where in excess of 100 may be seen in winter). At the beginning of the period in question there are some 40-50, mainly youngsters with only six or seven mature adults; with numbers generally declining with time.

This note reports on a spate of confirmed grey seal killings of adult eiders that have been witnessed around Great Cumbrae Island, mostly in the vicinity of Millport Bay $\left(55^{\circ} 45^{\prime} \mathrm{N}\right.$ $04^{\circ} 55^{\prime} \mathrm{W}$ ), recently (March-April 2001).

Table 1 itemizes the recent seal attacks witnessed locally in and around Millport Bay; a well-populated sea frontage. The total number of eiders killed over $\sim 3.5 \mathrm{~km}$ of coastline during this approximately 4 -week period is conservatively estimated to have been at least 20. The strandline carcasses have been excluded from this calculation. Although the times of day at which the attacks were observed may simply reflect the activity cycles of potential observers, it seems as if mainly females were being targeted for food and (maybe) males for sport. This could result from females being an easier prospect for the predator; being smaller and more easily captured and handled than males. Females, at this time of year would also be energetically profitable, i.e. in the period leading up to egg-laying (in May-June). Interestingly, by mid April, reports of seals attacking eiders in Millport Bay had dwindled to zero, coinciding with rapidly fluctuating numbers of seals on the Eileanns, as the juveniles began dispersing to sea.

While there is some evidence of kin-based spatial structuring on breeding colonies of grey seals, e.g. on North Rona (Pomeroy et al., 2000), there is little evidence of real kin groups outside the breeding season/sites. Dr S. Twiss (University of Durham, personal communication) is, however, of the opinion that grey seals probably do maintain kin relationships throughout the year. The balance of probability suggests that more than one seal was killing eiders (at least latterly).

Seals turning their predatory attentions to eiders may reflect the current poor status of fish stocks in the Clyde Sea area caused by overfishing (by both humans and seals).

I am grateful to all local people who have communicated their sightings either to me or to Skipper Howard McCrindle who, together with Mr Donald Patrick, have acted as enthusiastic data sleuths on my behalf. Mr Stewart Angus kindly sent me a copy of the short note in Hebridean Naturalist, and Dr Sean Twiss kindly commented on an earlier draft of the manuscript and suggested useful references and improvements.

\section{REFERENCES}

Morgan, R., 1986. Eider attacked by grey seal. British Birds, 79, p. 338.

Pomeroy, P.P., Twiss, S.D. \& Redman, P., 2000. Philopatry, site fidelity and local kin associations within grey seal breeding colonies. Ethology, 106, 899-919.

Ross, B.P. \& Furness, R.W., 2000. Minimising the impact of eider ducks on mussel farming. Glasgow: University of Glasgow.

Waltho, C.M., 2001. Eider in the Firth of Glyde: a 20th century success story. In Conference on the ecology and management of the Firth of Clyde, held at UMBS Millport under the auspices of The Firth of Clyde Forum, pp. 19-23. Edinburgh: Scottish Natural Heritage.

Submitted 4 July 2001. Accepted 1 November 2001. 